International Journal of Agriculture, Environment and Bioresearch

Vol. 4, No. 06; 2019

ISSN: $2456-8643$

\title{
DYNAMICS OF FLORISTIC DIVERSITY OF THE HAUT-SASSANDRA CLASSIFIED FOREST (CENTRAL WEST OF IVORY COAST) AND IMPLICATIONS FOR CONSERVATION
}

\author{
KOUAKOU Akoua Tamia Madeleine \\ Jean Lorougnon Guede University, BP 150 Daloa, Cote d'Ivoire \\ BARIMA Yao Sadaiou Sabas \\ Jean Lorougnon Guede University, BP 150 Daloa, Cote d'Ivoire \\ BOGAERT Jan \\ Liege University, Gembloux Agro-Bio Tech, Passage des Deportes 2, B-5030 Gembloux, Belgique
}

http://doi.org/10.35410/IJAEB.2019.4484

\begin{abstract}
The Haut-Sassandra Classified Forest (HSCF), located in the West-Center of Ivory Coast, has suffered from forest cover reduction during the last decade because of both the politico-military crises and claims for cocoa plantations. This reduction led to a decline in floristic diversity. The present study consists in a current characterization and analysis of floristic composition dynamics of HSCF over the past decade based on Kouamé's work in 1998. The methodology used consisted of systematic sampling of the flora along transects. This study shows that the HSCF embeds 622 plant species divided into 410 genera and 104 families. This flora is composed of 45 endemic species from West Africa and 5 endemic species from Ivory Coast. 16 rare species and 23 vulnerable species are composing the other special-status species. The regression of the forest cover has led to a major change in the flora with a decrease of about 40 $\%$ of the species richness compared to the inventories of Kouamé in 1998.
\end{abstract}

Keywords: conflict, floristic diversity, conservation, endemic species, degradation.

\section{INTRODUCTION}

Due to high population growth, global natural resources have been overexploited in recent years, leading to changes in ecosystems. This situation does not exclude the African continent, particularly the tropical regions (Mayaux et al., 2003; Achard et al., 2002). In West Africa, the rapid increase in land requirements in line with rapid population growth and spontaneous urbanization increases the pressure on natural resources and causes their degradation (Gillet et al., 2016). From 2005 to 2010 the annual deforestation rate in this part of Africa was estimated to $0.46 \%$ (FAO, 2010). However, this area is of great importance in the conservation of biodiversity because of its high endemism in both flora and fauna (Bakarr et al., 2004). Protected areas in several West African countries are thus subject to strong human pressures; such is the case in Mali (Diallo et al., 2011), Burkina Faso (Tankoano et al., 2016), Niger (Hamidou et al., 2012), Benin (Avakoudjo et al., 2014) or in Ivory Coast (Akoué et al., 2017, Vei, 2015). This phenomenon is explained by the depletion of land and fertility of arable land, leading people to migrate toward protected areas where soils are fertile (Youl et al., 2008). 
In Ivory Coast, most of the forest cover is limited to areas covered by national parks, reserves, classified and sacred forests (Chatelain et al., 2004). The country has 8 National Parks covering a total area of 1732,100 ha, 5 natural reserves covering 339,630 hectares, 16 botanical reserves with an area of 198,418 hectares, 231 classified forests of 4200,000 ha and 6702 sacred forests of 36,434 ha. Conservation method incorporates the traditional values of local people. As with most West African countries, these areas are subject to strong anthropogenic pressures due to agriculture and livestock (N'Da, 2008, Goné Bi et al., 2013).

The classified forest of Haut-Sassandra was declared permanent domain of the Ivorian state on October 6, 1969 (Kouamé, 1998). This forest has been described as a semi-deciduous dense forest with Celtis spp. and Triplochiton scleroxylon, from the mesophilic sector within the Guinean domain (Guillaumet and Adjanohoun, 1971). The flora of the HSCF is highly diversified both generically and specifically (Kouamé, 1998). In 1998, it contained 1047 plant species composing several endemic and special-status species of IUCN. Thus, it participated at $25 \%$ at the plant species level and $43 \%$ at the genus level in the general flora of Ivory Coast (Kouamé et al., 1998). This public space has experienced and still experiencing strong anthropic pressure due to the political and military conflicts that took place in Ivory Coast (Kouakou et al., 2018, Kouakou et al., 2017). To date, forest areas have decreased by $50 \%$ with an annual loss of $17 \%$ for crops and houses (Barima et al., 2016; Kouakou et al., 2015; Sangne et al., 2015). Some animal and plant species have recently been noted as absent in phytosociological surveys (Alohou et al., 2016; Kouamé et al., 2015). The flora of this forest has been little studied since the work of Kouamé in 1998.

In this context, the identification of the impact of HSCF land-use changes on its composition is essential to understand the dynamics of this forest. The purpose of this study is to determine the conservation value of the HSCF. We describe the floristic composition and the vertical structure of the HSCF. The first step was to analyze the general composition of the current HSCF stand by comparing the edge and center data to determine if the flora differs between these two areas. Secondly, the differences between the flora of the current forest fragments and the forest flora that existed in 1998 according to the work of Kouamé (1998) should be analyzed to determine the similarities between these data in order to evaluate the losses or gains due to degradation. Finally, the aim was to analyze the regeneration capacity of forest fragments.

\section{MATERIAL AND METHODS}

\subsection{Study area}

The HSCF is located in west-central Ivory Coast (Figure 1), between $6.85^{\circ}$ and $7.40^{\circ}$ north latitude and $6.98^{\circ}$ and $7.17^{\circ}$ west longitude. It covers an area of 102400 ha and is bounded on the west by the Sassandra River. The climate is of the wet equatorial type (Kottek et al., 2006) in two seasons with annual rainfall ranging between 1255 and $1550 \mathrm{~mm}$. The soils of this massif are essentially of the reworked ferralitic type (Perraud and De La Souchere, 1970). Although its vegetation is mainly found in the semi-deciduous moist semi-deciduous forest zone of Celtis spp and Triplochiton scleroxylon of the mesophilic sector, several types of plant formations are observed. In the North, there is a transition from the dense moist semi-deciduous forest to Celtis spp. and Triplochiton scleroxylon and that of the semi-deciduous moist dense 
forest at Aubrevillea kerstingii and Khaya grandifoliola. The center is characterized by numerous groupings on granitic rocks and some groupings on bare lateritic cuirass. The South is characterized by the humid dense semi-deciduous forest at Celtis spp. and Triplochiton scleroxylon typical of Monnier (1983) quoted by Kouamé (1998).

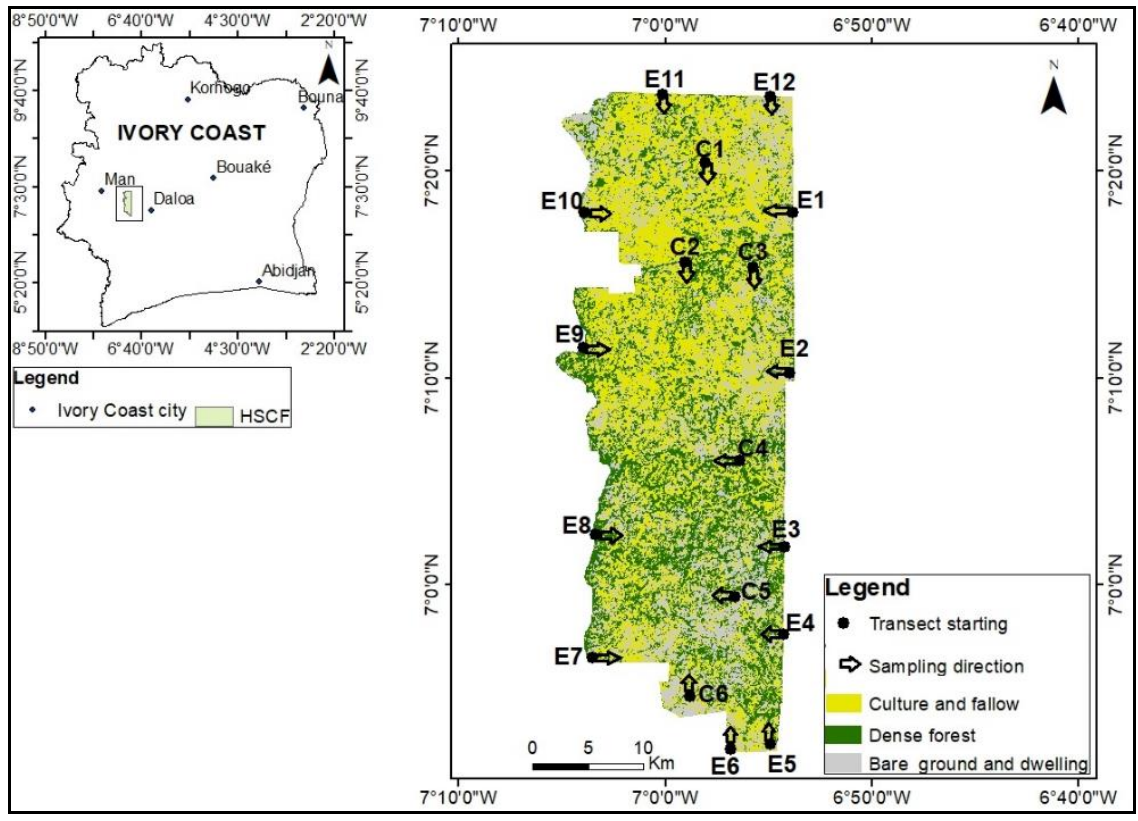

Figure 1: Location of the Haut-Sassandra Classified Forest (HSCF) in Côte d'Ivoire and sampling site $(\mathrm{E}=$ edge and $\mathrm{C}=$ center$)$ on a 2015 land cover map. Map source, Barima et al. (2016).

\subsection{Sampling method of flora}

Within the HSCF, 18 sites were randomly selected as starting points for transects whose position was considered as two factors (center and edge). Six transects were placed in the center and 12 at the edge (Figure 1). These two factors were considered in order to determine the differences in the floristic composition of these two zones due to the generalized degradation of the study area. The placement and sampling within the transects was done according to the method of Godron et al. (1969) which consists of surveying contiguous segments. The transects were $500 \mathrm{~m}$ long and $10 \mathrm{~m}$ wide and were perpendicular to one side of the HSCF. They were materialized by a rope $500 \mathrm{~m}$ long and supported by stakes at both ends. Each transect was subdivided into 20 sections $25 \mathrm{~m}$ long and $10 \mathrm{~m}$ wide, an area of $250 \mathrm{~m}^{2}$. The section was the experimental unit. All plant species encountered on each section were identified. The type of land use was also described to identify the segments covered by the forest.

\subsection{Analysis of floristic composition and diversity}

For each $250 \mathrm{~m}^{2}$ section, all plant species were identified according to the flora of Lebrun and Stork (1997) and Aké-Assi (2001-2002). Species individuals were also classified according to their height in 5 classes: I ( 0 to $2 \mathrm{~m}$ ), II ( 2 to $4 \mathrm{~m}$ ), III (4 to $8 \mathrm{~m}$ ), IV ( 8 to $16 \mathrm{~m}$ ), V (16 to 32 
m) and VI $(>32 \mathrm{~m})$ to assess the vertical structure of the forest. Then, the biological type of Raunkiaer (1934) of each species, their chorology and their conservation status were defined using respectively the Aké-Assi flora (2001-2002) and the red list of International Union for Nature Conservation established in 2015 (IUCN, 2015).

The biological type of a species expresses all the anatomical and morphological systems that characterize its vegetative system. The main biological types highlighted in this study are: epiphytes (Ep), parasites (Par), chamephytes (Ch), geophytes $(\mathrm{G})$, hemicryptophyte $(\mathrm{H})$, hydrophytes (Hyd), megaphanerophytes (MP), mesophanerophytes (mP), microphanerophytes (mp), nanophanerophytes (np), rheophytes (Rhe) and therophytes (Th).

Chorology can be defined as the geographical distribution of species according to their ecological preference. The chorological types considered in this study are: (1) endemic species from Ivory Coast (GCi); (2) endemic species from West Africa (GCW); (3) the humid dense forest species of the Guineo-Congolese domain (GC); (4) species belonging to the SudanoZambezian region (savannahs and open forests) (SZ); (5) species common to the GuineoCongolian region and the Sudano-Zambezian region (GC-SZ) and; (6) introduced or cultivated species (i).

The biodiversity indices used were alpha diversity $(\alpha)$, horizontal diversity and beta diversity ( $\beta$ ). Alpha diversity took into account the species richness and diversity index of Shannon and Weaver (1949). The diversity index of Shannon and Weaver is the most widely used diversity estimator, however, several authors, including O'Keeffe (2004); Chao and Shen (2003), have shown that the calculation method underestimates diversity in the rare species. Therefore, it is imperative to accompany the diversity index of Shannon and Weaver by other estimators to ensure the same evolution of the indices. In this study, we used the Simpson Diversity Index (1949) to validate the results obtained with the diversity index of Shannon and Weaver.

Horizontal diversity is an index that summarizes the distribution of species in the environment (Godron, 2012). We estimate it according to the Evenness index of Piélou (E). The beta diversity measures the differences between observations made in several places (Godron, 2012; Whittaker, 1960; Sørensen, 1948), we estimate it by the estimator of Sørensen (1948).

\subsection{Analysis of flora dynamics}

In this part the forest fragments determined from the description of the sections constituted the unit of measurement. The evolution of the flora was analyzed through a comparison of the Kouamé (1998) floristic data and those of the forest fragments sampled. The purpose of this analysis is to determine the current value of the HSCF for conservation and similarity to the initial forest. Data from forest fragments were compared with those of Kouamé (1998) in terms of biological and morphological types, families, endemic species from West Africa and Ivory Coast, and IUCN status (rare vulnerable and endangered).

The Braun-Blanquet area-species curve (1926) made it possible to determine the number of species per hectare for each of the data. Ecological information of forest fragment species was 
used to estimate degradation. Indeed, the level of degradation is estimated through the sum of the pioneer species specific contributions according to limits (Table I).

We have estimated the regeneration capacity (RC) of the HSCF generally through the formula of Rothe (Rothe, 1964) where when RC is less than $100 \%$, the regeneration is bad, when it is between 100 and $1000 \%$ regeneration is good and when it is greater than $1000 \%$, the regeneration is very good.

Table 1: Limits of specific contributions values of pioneer species determining the level of environment degradation.

\begin{tabular}{|l|l|}
\hline Type of environment & $\begin{array}{l}\text { specific contribution value }(\mathrm{SC}) \text { of } \\
\text { pioneer species }\end{array}$ \\
\hline Not degraded & $\mathrm{SC}<0,12$ \\
\hline Environment little degraded & $0,12<\mathrm{SC}<0.25$ \\
\hline Moderately degraded environment & $0,25<\mathrm{SC}<0,50$ \\
\hline Heavily degraded environment & $0,50<\mathrm{SC}<0,75$ \\
\hline Very strongly degraded environment & $\mathrm{SC}>0,75$ \\
\hline
\end{tabular}

\section{RESULT}

\subsection{Floristic composition of the Haut-Sassandra classified forest}

Sampling across all transects resulted in a floristic list of 622 species divided into 410 genera and 104 families. The most diverse families, with a number of species greater than or equal to 10, are in descending order Rubiaceae, Fabaceae, Euphorbiaceae, Moraceae, Apocynaceae, Poaceae, Annonaceae, Caesalpiniaceae, Asteraceae, Hippocrateaceae, Meliaceae, Sterculiaceae, Mimosaceae, Sapindaceae, Verbenaceae, Acanthaceae, Cucurbitatceae and Solanaceae. All these families are present at the edge of the forest as well as in the center of the forest. Of the 410 genera inventoried 234 are common to both zones, 136 are found only on the edge and 40 only on the inside. The Celtis and Triplochiton genera, which are the characteristic genera of the HSCF, are present both at the edge and inside. With regard to species, 322 are common to both areas, 232 have been inventoried only at the edge and 68 are found only indoors.

The floristic list is divided into 6 chorological types (Figure 2), the most dominant of which is that of the Guineo-Congolese zone (GC) with $67 \%$ of the species. Endemic species in West Africa (GCW), 45 in number, occupy a proportion of $7 \%$ (Figure 2) of the floristic list. Some of these species are common to both the edge and inland areas, while others occur only in one of two areas. In addition to the endemic species of West Africa, the endemism at the specific 
level is marked by the endemic species of Ivory Coast. The latter number of 5 are all at the edge and only two are present in the center. Among the chorological types are the species cultivated with a proportion of $3 \%$. This list highlights 5 categories of crop species: vegetables, food crops, cash crops and exploitable species. The general list of species indicates that in addition to the endemic species, 39 other species have a special status of which 16 are considered as rare species of Ivorian flora and 23 as vulnerable species on the Red list of International Union for the Conservation of Nature. Rare species are more represented at the edge than at the center of the forest, while vulnerable species have a larger number in the center of the forest than at the edge of the forest. Indeed, there are 13 rare species at the edge compared to 10 in the center while 20 vulnerable species are in the center against 15 at the edge.

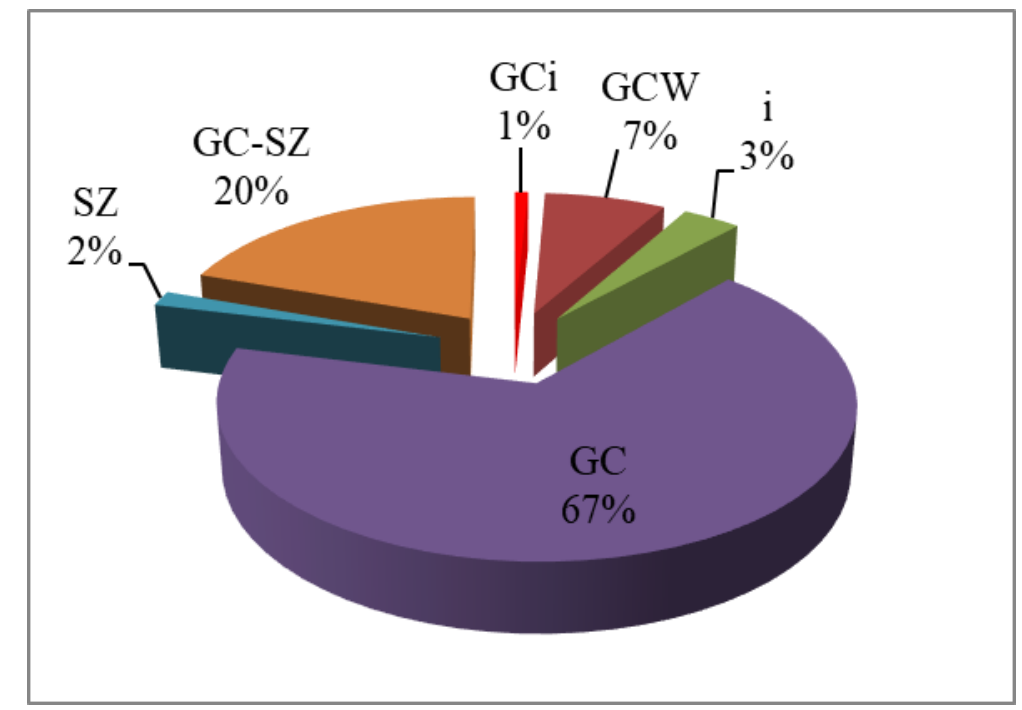

Figure 2: Chorological spectrum of Haut-Sassandra classified forest species.

Twelve (12) main biological types have been identified (Figure 3), with Microphanerophytes with $49 \%$ being the most represented. They are followed by Mesophanerophytes and Nanophanerophytes with $17 \%$ and $13 \%$ respectively. The weakest represented among the biological types are Hydrophytes, Rheophytes and Epiphytes, with an overall proportion of $1 \%$ represented by "others" in Figure 3. Height surveys highlight the types of strata encountered in the HSCF (Figure 4). The forest is dominated by individuals ranging in size from 0 to $2 \mathrm{~m}$ with $62 \%$ at the edge and 57\% indoors. The proportions observed at the level of the vertical structure do not reflect the trends observed with the biological types. Indeed, since the HSCF is a protected area dominated by microphanerophytes whose heights are between 2 and $8 \mathrm{~m}$, the dominant strata should be those between 2 and $4 \mathrm{~m}$ and 4 and $8 \mathrm{~m}$. Individuals greater than or equal to 32 are almost non-existent at both the edge and the center, whereas the forest has a proportion of $7 \%$ of megaphanerophytes, which are species of height greater than or equal to 32 $\mathrm{m}$. 


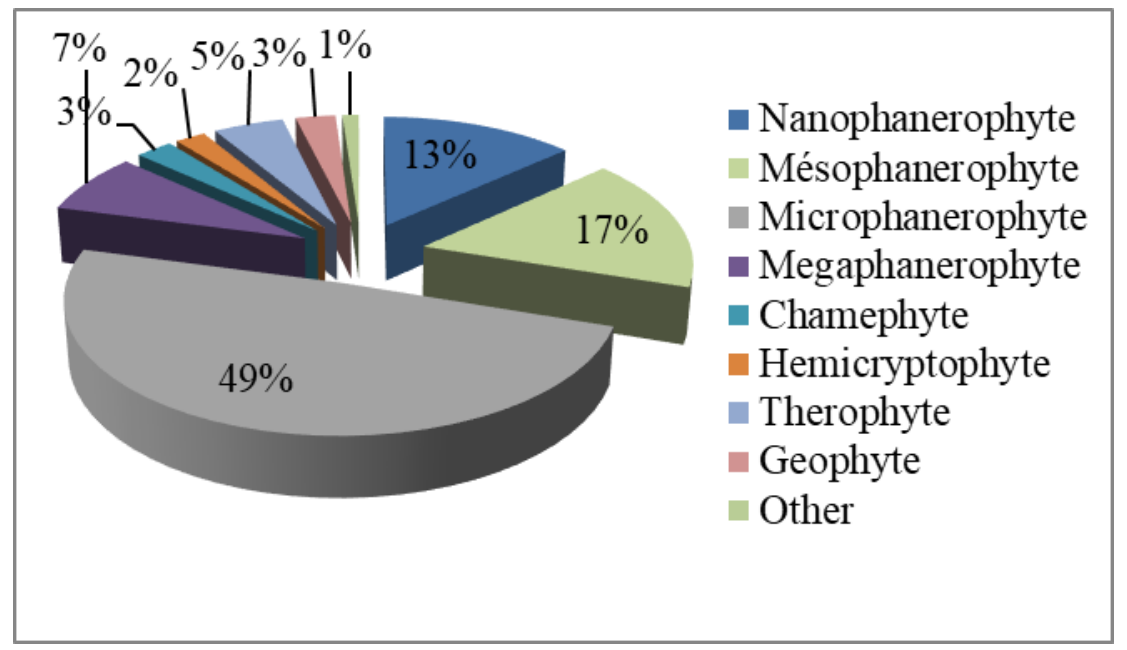

Figure 3: Biological spectrum of Haut-Sassandra classified forest species.

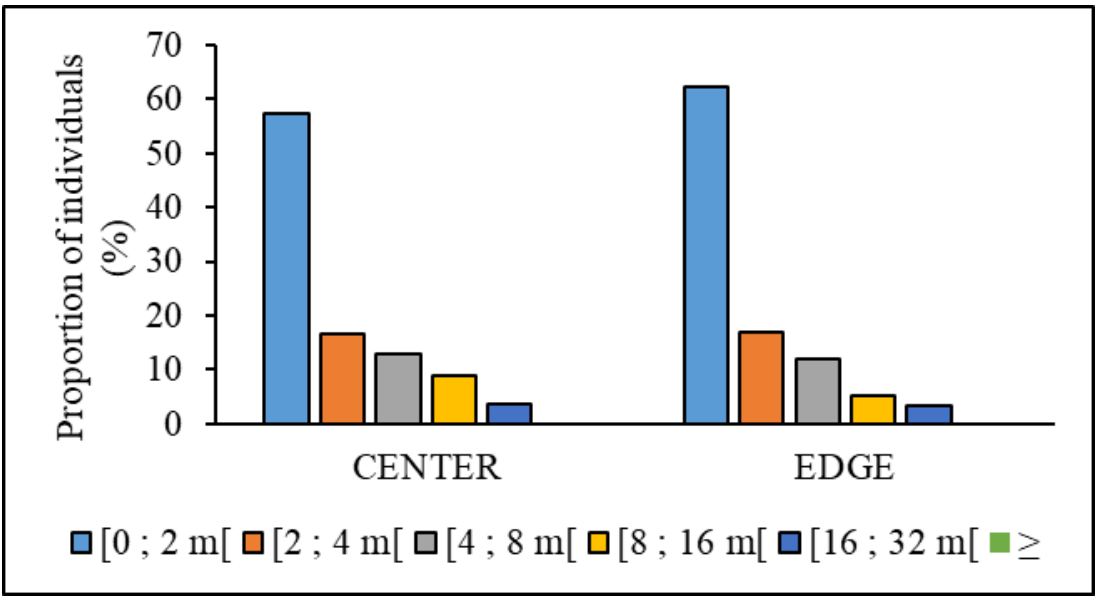

Figure 4 : Vertical structure of vegetation at the edge and center of Haut-Sassandra classified forest plant species.

\subsection{Diversity and heterogeneity of the Haut-Sasandra classified forest}

The floristic richness is important in all sampling sites. However, the first two most diverse transects are from the edge and are the "edge 3" transect with 196 species and the "edge 6" transect with 194 species located east and south respectively of the HSCF. For the interior, the most diverse transects are the "center 5" and "center 6" transects, each with 180 species, both located in the southern part of the HSCF.

All transects have high values of the Shannon diversity index with small variation (Table 2). The lowest value is in the "Edge 4" transect and is 3.04. These high values of the Shannon Diversity Index indicate high values of species richness associated with relatively homogeneous abundances between species. This important diversity is confirmed by the Simpson index, whose values all tend towards 1 . Homogeneity in the distribution of species is confirmed by high values 
of Pielou's Evenness index, which also vary slightly (Table 2). The lowest value being 0.91 and the highest being 0.95 recorded respectively in the "Edge 3" and "Edge 5" transects.

Table 2 : Diversity indices of different transects sampled at the edge and at the center of Haut-Sassandra classified forest

\begin{tabular}{|lllll|}
\hline & \multirow{2}{*}{$\begin{array}{l}\text { Species } \\
\text { richness }\end{array}$} & \multicolumn{2}{l}{$\begin{array}{l}\text { Diversity } \\
\text { index } \\
\text { Shannon }\end{array}$} & \multicolumn{2}{c|}{$\begin{array}{l}\text { Diversity } \\
\text { index }\end{array}$ of $\begin{array}{l}\text { Evenness } \\
\text { index } \\
\text { Pielou }\end{array}$} \\
\hline Center 1 & 165 & 4.7 & 0.987 & 0.92 \\
Center 2 & 146 & 4.6 & 0.986 & 0.92 \\
Center 3 & 113 & 4.31 & 0.982 & 0.93 \\
Center 4 & 156 & 4.7 & 0.987 & 0.92 \\
Center 5 & 180 & 4.8 & 0.988 & 0.91 \\
Center 6 & 180 & 4.8 & 0.988 & 0.92 \\
Edge 1 & 116 & 4.37 & 0.982 & 0.94 \\
Edge 2 & 110 & 4.29 & 0.981 & 0.93 \\
Edge 3 & 196 & 4.91 & 0.99 & 0.91 \\
Edge 4 & 175 & 3.04 & 0.989 & 0.92 \\
Edge 5 & 169 & 4.89 & 0.99 & 0.95 \\
Edge 6 & 194 & 4.98 & 0.991 & 0.94 \\
Edge 7 & 135 & 4.59 & 0.986 & 0.93 \\
Edge 8 & 148 & 4.61 & 0.986 & 0.92 \\
Edge 9 & 134 & 4.59 & 0.987 & 0.94 \\
Edge 10 & 134 & 4.55 & 0.986 & 0.93 \\
Edge 11 & 122 & 4.41 & 0.983 & 0.92 \\
Edge 12 & 130 & 4.41 & 0.983 & 0.91 \\
\hline
\end{tabular}

\subsection{Dynamics of forest fragments and state of degradation}




\subsubsection{Taxonomic dynamics}

We determined, on the different transects of a total of 360 sections of $250 \mathrm{~m}^{2}, 60$ sections with a forest fragment. All of these sections with an area of 1.5 ha present a floristic list of 376 species divided into 276 genera and 81 families, or 300 species per hectare (Figure 5). The parcels of Kouamé, total an area of 6 ha and present a floristic list of 470 species distributed between 293 genera and 83 families, or 214 species per hectare (Figure 5). At the specific level, 176 species are common to both lists giving a similarity of Sorensen of $41 \%$. Similarities in gender and family are more important with values of $63 \%$ and $82 \%$ respectively. With regard to the dominant taxa, the families with a number of species greater than or equal to 10 are 11 for our list and 12 for that of 1998. These families are for the new list: the Rubiaceae with 27 species, Fabaceae with 26 species, Apocynaceae and Euphorbiaceae with 20 species each, Moraceae with 16 species, Hippocrateaceae and Annonaceae with 14 species each, Sapindaceae with 11 species, Caesalpiniaceae, Poaceae and Sterculiaceae each with 10 species. species.

There is a great similarity among the dominant families; the differences are made by three families: Poaceae, Meliaceae and Combretaceae. Indeed, Meliaceae and Combretaceae are dominant in the old list and are not dominant in the new while Poaceae are dominant only in the new one. The genera with a number of species greater than or equal to 5 are for the new list: Salacia (9), Ficus (8), Diospyros (6), Drypetes (5) and Dioscorea (5). For the old list these genera are: Salacia (10), Combretum (10), Drypetes (9), Strychnos (8), Ficus (8), Diospyros (8), Rinorea (6) and Trichilia (5). By analyzing our lists of species, we realize that none of the species is ubiquitous on all surveys for both the new list and the old one. The 2015 data indicate that only one species, Nesogordonia papaverifera, was found on half of the stretches. As a result of this species, 4 other Tiliacora dinklagei, Griffonia simplicifolia, Diospyros canaliculata and Guibourtia ehie were recorded on $40 \%$ of the sections. These species, which seem to dominate the floristic list of forest fragments, were listed as dominant on the HSCF floristic list in 1998 with occurrences ranging from 75 to $95 \%$.

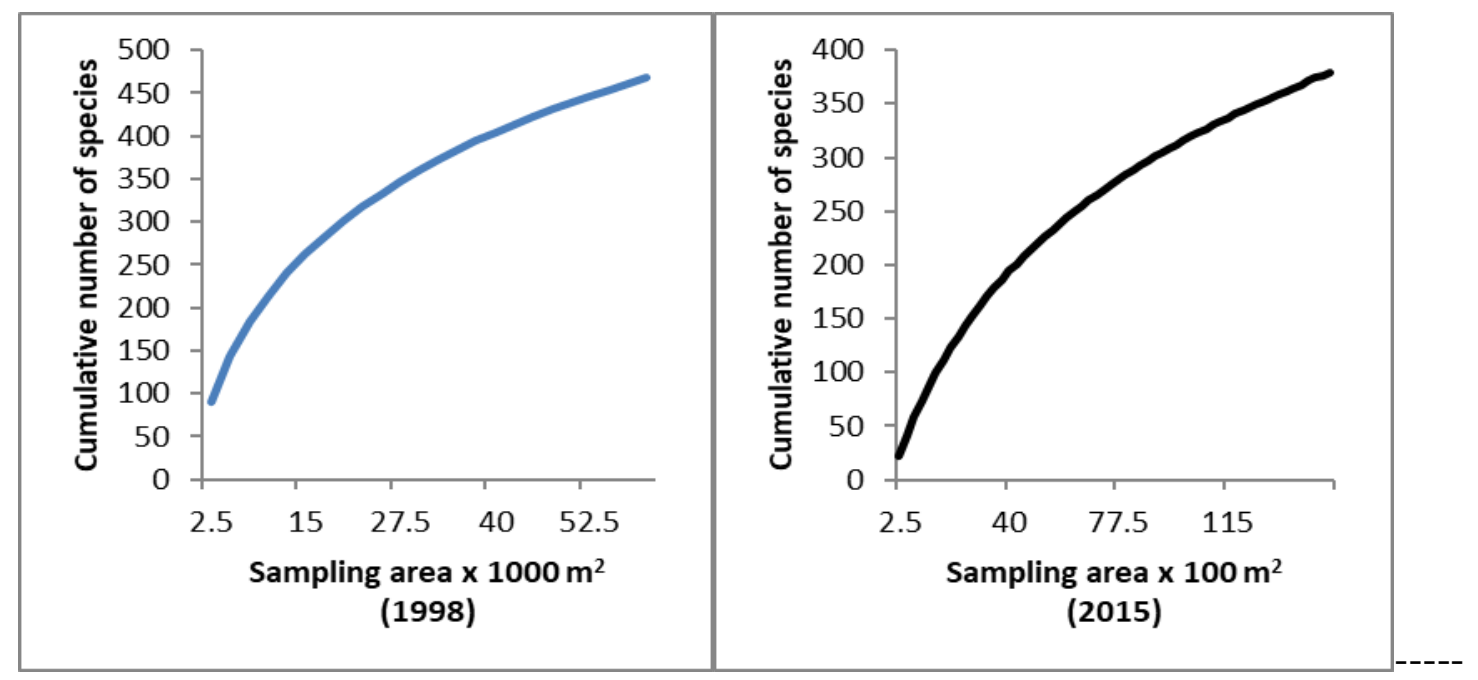


Figure 5 : Species-area curve obtained with the 1998 data (left) and the data from the forest fragments in 2015 (right) of Haut-Sassandra classified forest species.

Each of the two lists presents a list of conservation value species. The importance of these species is due to their endemism or conservation status according to the International Union for Conservation of Nature or according to the work of Aké-Assi. Regarding conservation status, the 2015 list presents 22 species, 10 of which are rare, 11 are vulnerable and one is rare and vulnerable. The 1998 list shows a larger number of species with special status. Numbering 40, the special status species on the 1998 list consist of 3 species, Placodiscus attenuatus, Pyrenacantha cordicula and Zanthoxylum leprieurii considered to be in danger of extinction and none of which were found in the 2015 list. in the general list or that of forest fragments. There are 11 rare species of which 7 are common to the list of forest fragments in 2015 and for the remaining 4, Lannea nigritana is present in the 2015 general list and the other 3, Erythrina vogelii, Maranthes robusta and Premna quadrifolia, are absent. We note the presence of 3 rare species in the list of 2015 that were not recorded by Kouamé in 1998: Hugonia rufipilis, Voacanga thouarsii and Isolona deightonii. Endemism at the specific level is marked for the forest fragments of 2015, by 4 endemic species of Ivory Coast (Baphia bancoensis, Chrysophyllum taïense, Cissus miegei and Geophila afzelii) and 34 endemic species from Africa. West. The endemic species of Ivory Coast from the 1998 list, 2 in number (Eugenia tabouensis and Gymnostemon zaizou), were not found in all the surveys in 2015. The number of vulnerable species (32 species), of the 1998 list is substantially equal to that of 2015 which is 31 . However only 12 species are common to these 2 lists and represent a similarity of $44 \%$.

\section{2-3-2 Dynamics at the level of biological and morphological types}

As with all surveys, forest fragments have a vertical structure dominated by individuals of low height. Kouamé (1998) noted a variation in stratification by plots. Indeed, some plots that he described as degraded, presented a stratification similar to that which we observed while other plots presented a codominance of the individuals of low height and those of height important. These observations lead us to determine the level of degradations of our forest fragments according to the method described in the methodology. We obtain a value of 0.38 which is between 0.25 and 0.50 , hence our forest segments are generally moderately degraded environments. This observation allows us to understand the vertical structure that corresponds to that of a degraded environment as indicated by Kouamé. The biological types on the forest fragments are dominated by phanerophytes, which is the case of all of our data and those of 1998. In terms of biological forms, there is a greater proportion of shrubs and lianas (Figure 6). The proportion of trees comes in third position in front of the herbs which constitute the least represented morphological type. These observations differ from those made by Kouamé (1998) although his observations show the dominance of shrubs and lianas. Indeed, in the list of 1998 the herbs occupy a place more important than that of the trees.

We used the regeneration rate of forest species to evaluate the potential of forest fragments to regenerate the forest. Forest species have a good regeneration rate of $140 \%$. Thus, although having a difference with the initial forest in view of our comparisons with the 
Kouamé's data, the forest segments through this good regeneration capacity could participate in the reconstitution of the HSCF.

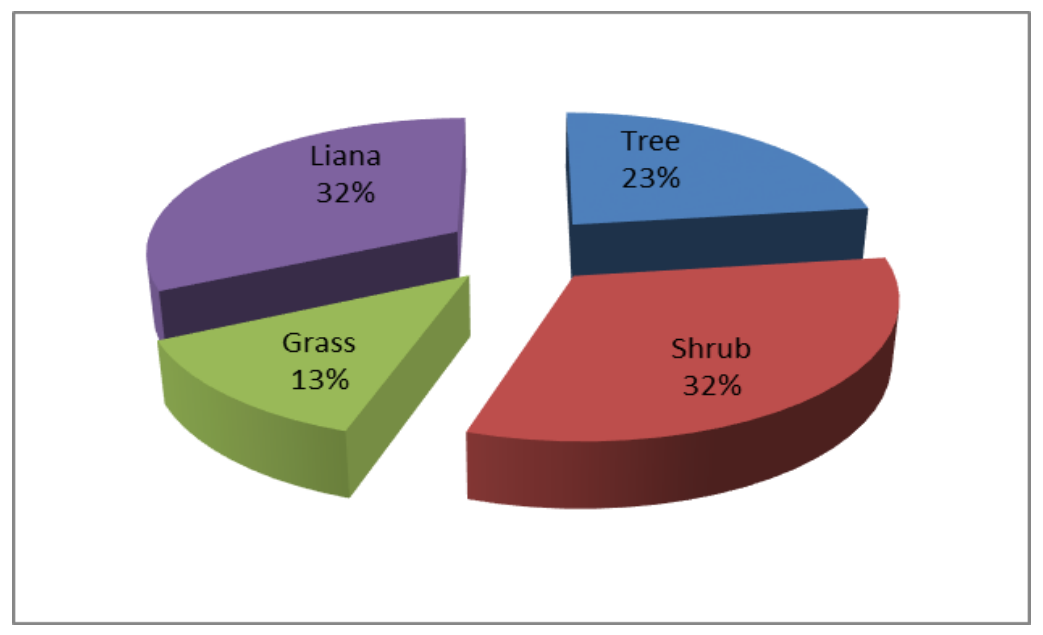

Figure 6: Morphological type spectrum of species in forest fragments of Haut-Sassandra classified forest species.

\section{DISCUSSION}

\subsection{Floristic composition of the Haut-Sassandra classified forest and importance for conservation}

The sampling method used makes it possible to make an inventory of the flora and to obtain information on the structure of the stands. However, in view of the evolution of the species-area curves, the minimum area of the HSCF is above $90000 \mathrm{~m}^{2}$ (area of $500 \mathrm{~m} \mathrm{x} 10 \mathrm{x}$ number of transects (18), so it would be useful for further studies of sample over a larger area to obtain a community more representative of HSCF flora.

The HSCF is an important ecosystem for the local population but also for the whole Ivory Coast. It was of great importance for the conservation of plant diversity in Ivory Coast because of its important floristic diversity, which accounted for $25 \%$ of the country's floristic diversity. Thus the HSCF is a reservoir of biological diversity that benefits local populations. According to Zanh et al. (2016), populations adjacent to HSCF are highly dependent on several non-timber forest products provided by certain species in this federal area. However, this space has undergone a profound change in its landscape over the past decade.

The land use pattern in HSCF is the primary cause of forest degradation. According to Assalé et al., (2016), the degradations in the HSCF are $95 \%$ of human origin and only $5 \%$ of natural origin. Degradations of anthropogenic origin consist mainly of crops, of which that of cacao is the most dominant. This dominance of cultures in the HSCF had been approached by several authors including Kouakou et al. (2015), Sangne et al. (2015) and Barima et al. (2016). Their work has shown a significant change in forest cover in the study area over the last decade. The landscape that was dominated by the forest in the early 2000s presented in 2015 a matrix 
dominated by crops followed by dwellings. In fact, because of the collapse of the lands in the rural domain, the infiltrations in the HSCF for the crops are more and more important. The infiltrated populations, in addition to the reduction of the forest cover by the clearings use cultural techniques which cause a loss of floristic diversity. We are thus witnessing a change in the floristic procession which is expressed on several levels.

At the specific level, the floristic list consists of several species cultivated with important occurrences. This observation confirms the predominance of crops in the HSCF. Slight variations in the Shannon diversity index and in the Evenness between the different inventoried sites indicate a homogeneous distribution of species throughout the forest (Coulibaly et al., 2013). Thus, the floristic diversity on the periphery would be the same as inside.

Despite this important presence of cultivated species, the different sites have a diversified flora with a Shannon diversity index generally higher than 4 and which indicates according to Yedomonhan (2009), a high diversity. This diversity, although important, differs from that of Kouamé (1998), which had recorded 1,047 species against 622 for the 2015 list, a probable species extinction of $40 \%$. However, the comparison of these specific riches with these two periods deserves to be qualified because of the methodological differences.

In terms of biological types, the composition of the HSCF is that of semi-deciduous dense forests with a predominance of phanerophytes and few epiphytes (Aké-Assi, 2002). The forest type of HSCF is confirmed by the dominance of Rubiaceae. Thus the forest as a whole still has the characteristics that were attributed to it at its creation. The HSCF presents a significant number of species with special status. The presence of these species indicates an importance of this space for the conservation of floristic diversity. The observed reduction in the number of these species could be due to a reduction in habitat mainly attributable to agriculture as observed in other protected areas in Ivory Coast (Adou Yao et al., 2013).

\subsection{Reconstitution of the classified forest of Haut-Sassandra}

Our results regarding the level of degradation and the vertical structure of HSCF vegetation reflect a degraded environment. According to Ouedraogo (2006) a stable stand is characterized by an L-shaped structure consisting of a large number of small individuals and a steady decline in the number of individuals from one height class to another. This evolution of the structure is not consistent with that obtained in the HSCF where although being an L-shaped structure, we have a systematic decrease in the number of individuals passing from small individuals to large individuals. This structure is the result of agriculture, which is the main degradation factor in the HSCF (Barima et al., 2016, Assalé et al., 2016). Farming methods implemented by farmers in HSCF have the effect of eliminating undergrowth through clearing and eliminating large trees by burning (Kouakou et al., 2015). Thus, the plantation establishment process resets the initial stand by creating favorable conditions for the establishment of a new stand (Brassard and Chen, 2006), hence the differences between the floristic lists of the 1998 HSCF. (Kouamé, 1998) and that of 2015. This cultural method also explains the vertical structure observed in the HSCF. In fact, after the clearing of the undergrowth and the elimination of large trees, the vegetation consists in part of cultivated species and young plants of wild 
species developing under dead trees under the effect of fire. According to our results, these seedlings consist partly of forest species, reflecting the possibility of a return to the forest. However, if the forest is reconstituted, it would be different from that which existed before the intervention of the current pressures because of the differences observed between the different floristic lists.

Cropping techniques in HSCF, although they are slash-and-burn techniques, are different from those generally used in African regions. Slash-and-burn agriculture consists of clearing and felling. These actions are followed by burning that will promote soil fertilization (Carriere, 2002). Also in this technique the felling is selective because the populations save or protect some trees during the creation of the plantation (Carriere, 2002). These trees promote forest regeneration. Indeed, according to Sirois et al. (1998), the crown of trees spared from slaughter is a refuge for frugivorous seed-dispersing animals. The seeds deposited under these trees find the physicochemical conditions favorable to their development. This phenomenon occurs under several trees, in the fallow period we are witnessing the creation of several forest blocks that through trade contribute to forest recovery (Carriere, 2002). The resumption of vegetation implies an alternation of culture and rest of the earth. This is not the case in HSCF where farmers practice permanent agriculture. These farmers are for the most part migrants from the countries of the interland in search of better living conditions. These replace the entire forest with crops. In such a context of land use patterns in the HSCF, rebuilding the initial forest is impossible.

\section{CONCLUSION}

At the end of this study, it can be noted that in floristic terms, the Haut-Sassandra classified forest still contains a large number of species. These 622 species present 89 with special status of which 45 are endemic to West Africa, 5 are endemic to Ivory Coast, 16 are considered as rare species of Ivorian flora and 23 as vulnerable species according to the red list of the International Union for the Conservation of Nature. According to diversity indices, HSCF is diversified at both the edge and the center with a fair distribution of species. The HSCF is a degraded area according to the results concerning the level of degradation but also according to previous studies on spatial dynamics. However, the general floristic diversity in addition to the large number of species with special status gives this area a conservation value of the biological diversity of Ivory Coast. With regard to the regeneration capacity of the forest, the HSCF has a high rate of forest species regeneration. However, although having a large diversity, the current flora of the HSCF shows only $40 \%$ similarity with the flora that existed there before the advent of anthropic pressures. Thus, although having a high capacity for forest regeneration, in the absence of anthropogenic pressures, the forest that would be set up would be different from that which existed there. Ultimately, the method of rehabilitation to recover the original flora would be to intervene in regeneration by reintroducing the species that are no longer there while controlling the ecological conditions favorable to their development.

\section{REFERENCE}

ACHARD, F., EVA, D. H., STIBIG, H-J, MAYAUX, P., GALLEGO, J., RICHARDS, T. and MALINGREAU, J.-P., 2002. Determination of Deforestation Rates of the World's Humid Tropical Forests. Science, 297 : 999-1002. 
ADOU YAO, C. Y., KPANGUI, K. B., ADOU, L. M. M., VROH, B. T. A. and N'GUESSAN, K. E., 2013. Diversité floristique et valeur de la forêt sacrée Bokasso (Est de la Côte d'Ivoire) pour la conservation. Vertigo, 13(1) : 1-16.

AKE-ASSI, L., 2002. Flore de la Ivory Coast: catalogue systématique, biogéographie et écologie. Boissiera 58, 401 p.

AKE-ASSI, L., 2001. Flore de la Ivory Coast1, catalogue, systématique, biogéographie et écologie. Genève, Suisse : Conservatoire et jardin Botanique de Genève ; Boissiera 57, 396 p.

AKOUE, Y. C., ADAMAN, S. and ZON, D. A., 2017. Parc national du Banco, un patrimoine entre destruction et conservation : réalité et enjeux d'une gestion durable. Eur. Sci. J., 13(2) : 182-195.

ALOHOU, E. C., OUINSAVI, C. and SOKPON, N., 2016. Fragmentation des écosystèmes forestiers : Définitions des concepts et évolution des méthodes d'évaluation. IJIAS, 17(2): 474486.

ASSAlE, A. A. Y., BARIMA, Y. S. S., KOUAKOU, K. A., KOUAKOU, A. T. M. and BOGAERT, J., 2016. Agents de dégradation d'une aire protégée après une décennie de conflits en Ivory Coast: cas de la forêt classée du Haut-Sassandra. Int. J. Inno. Sci. Res, 22(1) : 123-133.

AVAKOUDJO, J., MAMA, A., TOKO I., VALENTIN, K. V. and SINSIN, B., 2014. Dynamique de l'occupation du sol dans le Parc National du W et sa périphérie au nord-ouest du Bénin. Int. J. Biol. Chem. Sci. 8(6): 2608-2625.

BAKARR, M., OATES, J. f., FAHR J., PARREN, M. P. F., RÖDEL, M.-O. and DEMEY, R., 2004. Guinean forests of West Africa. In: MITTERMEIER, R. A., GIL, P. R., HOFFMAN, M., PILGRIM, J., BROOKS, T., MITTERMEIER, C. G., LAMOREUX, J. and DA FONSECA, G. A. B. (Eds.). Hotspots Revisited: Earth's Biologically Richest and Most Endangered Terrestrial Ecoregions. CEMEX \& Conservation International, Mexico City and Washington, D. C., 123130.

BARIMA, Y. S. S., KOUAKOU, A. T. M., BAMBA, I., SANGNE, Y. C., GODRON, M., ANDRIEU, J. and BOGAERT, J., 2016. Cocoa crops are destroying the forest reserves of the classified forest of Haut-Sassandra (Ivory Coast). Glob. Ecol. Conserv., 8 : 85-98.

BRASSARD, B. W. and CHEN, H. Y. H., 2006. Stand structural dynamics of North American boreal forests. Crit. Rev. Plant Sci., 25(2) : 115-137.

BRAUN-BLANQUET, J., 1926. Etudes phytosociologiques en Auvergne, rapport sur une excursion interuniversitaire. Arvernia, 96 p.

CARRIERE, M. S., 2002. L'abattage sélectif : une pratique agricole ancestrale au service de la régénération forestière. Bois for. Trop., 272 (2) : 45-62.

CHAO, A. and SHEN, T.-J., 2003. Nonparametric estimation of Shannon's diversity index when there are unseen species in sample. Environ. Ecol. Stat., $10: 429-443$. 
CHATELAIN, C., DAO H., GAUTIER, L. and SPICHIGER, R., 2004. Forest cover changes in Ivory Coastand Upper Guinea. In : Biodiversity of West African Forests, An Ecological Atlas of Woody Plant Species CABI Publ., $1^{\text {ere }}$ édition : 15-32.

COUliBAly, S., OUATTARA, D., EDORH, T., KOUDEGNAN, C. M. M., and KAMANZI K., 2013. Diversité et configuration de la flore ligneuse autour d'un rucher en zone de transition foret-savane de la Côte d'Ivoire. Eur. Sci. J., 9(6) : 227-239.

DIALLO, H., BAMBA, I., BARIMA, Y. S. S., VISSER, M., BALlO, A., MAMA, A., VRANKEN, I., MAIGA, M. and BOGAERT J., 2011. Effets combinés du climat et des pressions anthropiques sur la dynamique évolutive de la végétation d'une zone protégée du Mali (Reserve de Fina, Boucle du Baoulé). Secheresse, 22 : 97-107.

FAO, 2010. Evaluation des ressources forestières mondiales 2010 Rapport principal, Rome, Etude FAO forêts 163, 377p.

GILlet, P., VERMEUlEN, C., FEINTRENIE, L., DESSARD, H., and GARCIA, C., 2016. Quelles sont les causes de la déforestation dans le bassin du Congo ? Synthèse bibliographique et études de cas. Biotechnol. Agron. Soc. Environ., 20(2), 183-194.

GODRON, M., 2012. Ecologie et évolution du monde vivant. Harmattan, Paris, 385 p.

GODRON, M., DAGET, P. and EMBERGER, L., 1969. Vade-mecum pour le relevé méthodique de la végétation et du milieu in code pour le relevé méthodique de la végétation et du milieu. Paris : Centre national de la recherche scientifique, $170 \mathrm{p}$.

GUILLAUMET, J-L. and ADJANOHOUN, E., 1971. La végétation de la Côte d'Ivoire. In : AVENARD, J. M., ELDIN, E., GIRARD, G., SIRCOULON, J., TOUCHEBEUF, P., GUILLAUMET, J-L., ADJANOHOUN, E., PERRAUD, A., (Eds). Le milieu naturel de la Côte d'Ivoire. ORSTOM, Paris : 57-266.

HAMIDOU, A., BOUBE M., ALI, M., MAHAMANE, S. and ABASSA, I., 2012. Caractérisation de la dynamique spatio-temporelle de l'occupation des terres dans le complexe des forêts classées de Dan kada Dodo-Dan Gado (région de Maradi, Niger). Journal des Sciences de l'Environnement, 1(1) : 16-26.

KOTTEK, M., GRIESER, J., BECK, C., RUDOLF and RUBEL, F., 2006. World Map of the Köppen Geiger climate classification updated. Meteorol. Z., 15(3) : 259-263.

KOUAME, N. F., AHIMI, A. O., BORAUD, K.N.M. and N'GUESSAN, K. E., 2015. Floristique diversity under anthropogenic activities in the protected forest of Duekoué and Scio in southwestern Côte d'Ivoire. Afr. J. of Plant Sci., 9 (3) : 128-146.

KOUAME, N.F., 1998. Influence de l'exploitation forestière sur la végétation et la flore de la forêt classée du Haut-Sassandra (Centre-Ouest de la Côte d'Ivoire). Thèse de Doctorat de troisième cycle de l'Université de Cocody (Abidjan), 203 p. 
KOUAME, N. F., TRA BI, F. H., ETIEN, T. D., and TRAORE, D., 1998. Végétation et flore de la forêt classée du Haut-Sassandra en Côte d'Ivoire. Revue CAMES, 00 : 28-35.

KOUAKOU, A. T. M., ASSALE, A. A. Y. and BARIMA, Y. S. S., 2018. Impact des pressions anthropiques sur la flore de la forêt classée du Haut-Sassandra (Centre-Ouest de la Côte d'Ivoire). Tropicultura, 36(2) : 155-170.

KOUAKOU, A. T. M., BARIMA, Y. S. S., KONATE, S., BAMBA, I., KOUADIO, Y. J. and BOGAERT, Y., 2017. Gestion des forêts domaniales en période de conflits : cas de la forêt classée du Haut-Sassandra, Centre-Ouest de la Côte d'Ivoire. Int. J. Biol. Chem. Sci., 11(1) : 333-349.

KOUAKOU, A. T. M., BARIMA, Y. S. S., KOUAKOU, K. A, KOUAME, N. F., BOGAERT, J. and KOUADIO, Y. J., 2015. Forest Dynamics in the North of the Classified Forest of HautSassandra During the Period of Armed Conflicts in Ivory Coast, American J. of L. Sci., 3(5) : 375-382.

LEBRUN, J. P. and STORK, A.L., 1997. Enumération des plantes à fleurs d'Afrique tropicale. Conservatoire et Jardin Botaniques de la Ville de Genève, 257 p.

MAYAUX, P., GOND, V., MASSART, M., PAIN-ORCET, M. and ACHARD, F., 2003. Evolution du couvert forestier du bassin du Congo mesurée par télédétection spatiale. Bois for. Trop., 277(3) :45-52.

N'DA, D.H., 2008. Etude et suivi par télédétection et système d'informations géographiques d'une aire protégée soumise aux pressions anthropiques : cas du Parc National de la Marahoué. Thèse de Doctorat, Université de Cocody, Abidjan, Côte d'Ivoire, 175 p.

O'KEEFFE, J., 2004. Measuring Biological Diversity. Afr. J. Aquat. Sci., 29(2) : 285-286.

OUEDRAOGO, I., 2006. Land use dynamics in Bieha district, Sissili Province ; southern Burkina Faso, West Africa. IJAAAS, $1: 18-34$.

PERRAUD, A. and DE LA SOUCHERE, P., 1971. Esquisse pédologique de la Côte d'Ivoire. Ech. 1/500000e feuille Sud-Ouest. ORSTOM, Adiopodoume, 171 p.

RAUNKIAER, C., 1934. The life forms of plants and statistical plant geography. Oxford, 648 p.

ROTHE, P. L., 1964. Régénération naturelle en forêt tropicale : le Dipterocarpus dyeri (Dau) sur le versant cambodgien du golfe du Siam. Bois et For. Trop., 8, 386-397.

SHANNON, C. E. and WEAVER, W., 1949. The mathematical theory of communication. Univ. Illinois, USA, $132 \mathrm{p}$.

SIMPSON, E. H., 1949. Measurement of diversity. Nature, 163 : 688 p. 
SIROIS, M.-C., MARGOLIS, H. A. and CAMIRE, C., 1998. Influence of remnant trees on nutrients and fallow biomass in slash-and-burn agroecosystems in Guinea. Agroforestry Systems, $40: 227-246$.

SØRENSEN, T., 1948. A method of establishing groups of equal amplitude in plant sociology based on similarity of species content. Det Kongelige Danske Videnskabernes Selskab. Biol. Skr., (5) $4: 1-34$.

SANGNE, Y. C., BARIMA, Y. S. S., BAMBA, I. and N'DOUME C-T. A., 2015. Dynamique forestière post-conflits armés de la Forêt classée du Haut-Sassandra (Côte d'Ivoire). Vertigo, $15(3): 1-18$.

TANKOANO, B., SANON, M., DIBI, N. H., YAMEOGO, J. T. and SOMDA I., 2016. Pression anthropique et dynamique végétale dans la forêt classée de Tiogo au Burkina Faso : apport de la télédétection. Tropicultura, 34 (2) : 193-207.

UICN, 2015. Liste rouge des espèces menacées, Union Internationale pour la Conservation de la Nature, version 2015.

VEÏ, K. N., 2015. Dynamique spatio-temporelle de la réserve du Haut Bandama en Côte d'Ivoire. Germivoire, 2 :197-209.

WHITTAKER, R. H., 1960. Vegetation of the Siskiyou Mountains, Oregon and California. Ecol. Monogr., 30(3) : 279-338.

YEDOMONHAN, H., 2009. Plantes mellifères et potentialités de production de miel en zones guinéenne et soudano-guinéenne au Bénin, Thèse de Doctorat, Université d'Abomey-Calavi, Bénin, 273p.

YOUL, S., BARBIER, B., MOULIN, C-H, MANLAY, R. J., BOTONI, E., MASSE, D., HIEN, V. and FELLER C. 2008. Modélisation empirique des principaux déterminants socioéconomiques de la gestion des exploitations agricoles au Sud-Ouest du Burkina Faso. Biotechnol. Agron. Soc. Environ. 12(1) : 9-21.

ZANH, G. G., BARIMA, Y. S. S., KOUAKOU, K. A. and SANGNE, Y. C., 2016. Usages des produits forestiers non-ligneux selon les communautés riveraines de la forêt classée du HautSassandra (Centre-Ouest de la Côte d'Ivoire). Int. J. Pure App. Biosci. 4(5) : 212-225. 